(C) 2018, THE AUTHORS. Published by FASS Inc. and Elsevier Inc. on behalf of the American Dairy Science Association ${ }^{\circledR}$.

This is an open access article under the CC BY-NC-ND license (http://creativecommons.org/licenses/by-nc-nd/3.0/).

\title{
Selected reaction monitoring mass spectrometry of mastitis milk reveals pathogen-specific regulation of bovine host response proteins
}

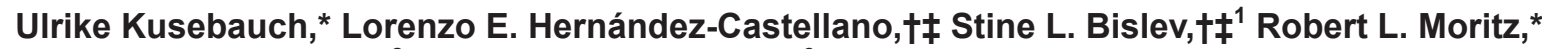 \\ Christine M. Røntved, $\ddagger^{2}$ and Emøke Bendixen $\ddagger^{3}$ \\ *Institute for Systems Biology, Seattle, WA 98109 \\ †Department of Molecular Biology and Genetics, Aarhus University, 8000 Aarhus, Denmark \\ ‡Department of Animal Science, Aarhus University, 8830 Tjele, Denmark
}

\section{ABSTRACT}

Mastitis is a major challenge to bovine health. The detection of sensitive markers for mastitis in dairy herds is of great demand. Suitable biomarkers should be measurable in milk and should report pathogenspecific changes at an early stage to support earlier diagnosis and more efficient treatment. However, the identification of sensitive biomarkers in milk has remained a challenge, in part due to their relatively low concentration in milk. In the present study, we used a selected reaction monitoring (SRM) mass spectrometry approach, which allowed the absolute quantitation of 13 host response proteins in milk for the first time. These proteins were measured over a 54-h period upon an in vivo challenge with cell wall components from either gram-negative (lipopolysaccharide from Escherichia coli; LPS) or gram-positive bacteria (peptidoglycan from Staphylococcus aureus; PGN). Whereas our data clearly demonstrate that all challenged animals have consistent upregulation of innate immune response proteins after both LPS and PGN challenge, the data also reveal clearly that LPS challenge unleashes faster and shows a more intense host response compared with PGN challenge. Biomarker candidates that may distinguish between gram-negative and gram-positive bacteria include $\alpha-2$ macroglobulin, $\alpha-1$ antitrypsin, haptoglobin, serum amyloid A3, cluster of differentiation 14, calgranulin B, cathepsin C, vanin-1, galectin 1, galectin 3, and IL-8. Our approach can support further studies of large cohorts of animals with natural occurring mastitis, to validate the relevance of these suggested biomarkers in dairy production.

Key words: mastitis, selected reaction monitoring, host response proteins, lipopolysaccharide, peptidoglycan

Received December 19, 2017.

Accepted February 16, 2018.

${ }^{1}$ Current affiliation: Vikan A/S, 7800 Skive, Denmark.

${ }^{2}$ Current affiliation: CMR On-site RD, 9220 Aalborg, Denmark.

${ }^{3}$ Corresponding author: ebx@mbg.au.dk

\section{INTRODUCTION}

Mastitis, an inflammatory reaction of the mammary gland, represents a major challenge to animal health in the dairy farming industry, compromising both animal welfare and economic gain (Hogeveen et al., 2011). Escherichia coli and Staphylococcus aureus are 2 of the major mastitis-causing pathogens in the mammary gland, leading different progressions of pathology (Bannerman, 2009; Schukken et al., 2011; Wall et al., 2016a). Mastitis caused by E. coli is usually associated with acute inflammation and severe clinical symptoms, whereas Staph. aureus infections mainly result in chronic and subclinical infections (Yang et al., 2008; Hernández-Castellano et al., 2017a). The innate immune system responds to the earliest stages of the infection and relies on cell surface receptors that recognize conserved microbial molecules (Schukken et al., 2011) as well as soluble components, such as acute phase proteins and cytokines, which are secreted into blood and milk (Aitken et al., 2011).

Regulation of bovine host response proteins is not fully understood, but accumulating evidence suggests that host response is specifically tailored to different types of mastitis-causing pathogens (Bannerman, 2009; Griesbeck-Zilch et al., 2008; Yang et al., 2008). Hence, the abundance of specific host response proteins secreted in milk may provide information for early monitoring of mastitis pathogens. Validated markers could be integrated in automated milking systems to provide routine surveillance of animal health and help to improve detection, diagnosis, and treatment of mastitis in dairy herds. Nonetheless, accurate quantification of specific proteins in milk is still technically challenging. Shotgun proteomics has been applied to identify mastitis biomarkers in bovine milk (Danielsen et al., 2010; Boehmer, 2011); however, these studies have failed to report less-abundant proteins related to the immune response, such as cytokines and their receptors. This is partly due to the stochastic nature of the precursor selection in shotgun MS, which is bi- 
ased toward the more-abundant proteins in complex biological samples such as milk, blood, and tissues (Domon and Aebersold, 2010; Hernández-Castellano et al., 2014, 2015). Selected reaction monitoring (SRM) by MS was developed to provide increased sensitivity, dynamic range, and reproducibility of protein analyses (Picotti and Aebersold, 2012). The SRM approach provides absolute quantification of selected protein-specific peptides by paired correlation to stable isotope-labeled standards and is currently the method of choice for sub-femtomolar quantification of specific protein biomarkers across diverse biological samples, including mammalian tissues and body fluids (Ebhardt et al., 2015; Hernández-Castellano et al., 2016; Kusebauch et al., 2016).

Lipopolysaccharides have been used in several studies to mimic intramammary $E$. coli mastitis in vivo as well as in cultured mammary epithelial cells (Burvenich et al., 2003; Vels et al., 2009; Wall et al., 2016b). Similarly, peptidoglycans (PGN) have been used to mimic intramammary Staph. aureus mastitis, but so far only in cultured bovine mammary epithelial cells (Mount et al., 2009; Im et al., 2014; Sulabh et al., 2016) and the effect of PGN on expression of host response proteins in live animals remains uncharacterized. Based on these considerations, the aim of our study was to investigate a time-resolved and parallel monitoring of bovine host response to LPS and PGN, measured by the absolute quantity and concentration dynamics of 13 specific host response proteins in milk.

\section{MATERIALS AND METHODS}

\section{Animals and Treatments}

Six healthy Danish Holstein-Friesian cows in midlactation were randomly selected for 2 parallel intramammary challenge experiments. Three cows were inoculated with LPS (LPS O111:B4, Sigma Aldrich A/S, Brøndby, Denmark) and 3 cows were similarly inoculated with PGN (Sigma Aldrich A/S). Infusions were performed in one quarter with $10 \mathrm{~mL}$ of sterile $0.9 \% \mathrm{NaCl}$ containing either $20 \mu \mathrm{g}$ of LPS or PGN per milliliter (total dose of $200 \mu \mathrm{g}$ ) $3 \mathrm{~h}$ after the morning milking following procedures described in Vels et al. (2009). Before the infusions, milk SCC were measured in all quarters, resulting in SCC $<100,000$ cells $/ \mathrm{mL}$. The SCC was determined directly upon sampling according to Fogsgaard et al. (2012) and Torres et al. (2014) using a DeLaval somatic cell counter (DeLaval International AB, Tumba, Sweden).

All procedures and experimental handling of animals were approved by the Danish Animal Experiments Inspectorate (license no 210601-075, J.no. 2001/561-410) and conducted in the dairy barn facilities at the Department of Animal Science, Aarhus University.

\section{Milk Samples}

Milk samples were collected from the infused quarter as well as from an unchallenged, negative control quarter at 6 different time points from each cow: 0, 4, 8, 12, 24, and $54 \mathrm{~h}$ after LPS and PGN inoculations. The SCC was determined directly upon sampling as described above. Milk samples were filtered using a 100- $\mu$ m nylon mesh (Sefar AG, Thal, Switzerland) cut to fit a $6-\mathrm{cm}$ polystyrene funnel and stored at $-20^{\circ} \mathrm{C}$ until further processing. Milk samples were thawed at $37^{\circ} \mathrm{C}$ to ensure homogenization of milk fat. The casein proteins were precipitated by adjusting the $\mathrm{pH}$ to 4.6 by adding $0.06 \%$ trifluoroacetic acid (TFA) to the milk (9:1), followed by centrifugation at $15,000 \times g$ for $10 \mathrm{~min}$ at $10^{\circ} \mathrm{C}$. After that, the milk whey fraction (supernatant) was collected for further analysis. Protein concentration was determined using the Pierce BCA Protein Kit (VWR-Bie \& Berntsen A/S, Herlev, Denmark) with BSA as standard, according to manufacturer's instructions.

\section{Digestion of Milk Proteins}

Each whey sample $(200 \mu \mathrm{g}$ of protein) was precipitated using ice-cold acetone and resuspended in $19 \mu \mathrm{L}$ of digestion buffer (0.5 $M$ triethylammonium bicarbonate, $0.1 \% \mathrm{vol} / \mathrm{vol}$ SDS). Protein disulfide bonds were reduced with $1 \mu \mathrm{L}$ of $50 \mathrm{mM}$ Tris (2-carboxyethyl) phosphine hydrochloride to reach a final concentration of $2.5 \mathrm{mM}$ Tris (2-carboxyethyl)phosphine hydrochloride and incubated at $60^{\circ} \mathrm{C}$ for $1 \mathrm{~h}$. Proteins were then alkylated by adding $1 \mu \mathrm{L}$ of $200 \mathrm{~m} M$ iodoacetic acid and samples were incubated at room temperature for $10 \mathrm{~min}$ in the dark. Proteins were digested with trypsin (1:10 wt/wt; Sciex, Framingham, MA) at $37^{\circ} \mathrm{C}$ for $16 \mathrm{~h}$. Samples were passed through a centrifugal filter (pore size $0.2 \mu \mathrm{m}$; VWR International, West Chester, PA) for $10 \mathrm{~min}$ at $10,000 \times \mathrm{g}$ at $10^{\circ} \mathrm{C}$ and dried down in a vacuum centrifuge.

\section{Mixed-Mode Cation Exchange Purification of Milk Peptides for SRM Analysis}

Dried peptides $(50 \mu \mathrm{g})$ were dissolved in $2 \%$ (vol/ vol) acetonitrile (ACN), 0.1\% (vol/vol) formic acid $(\mathrm{pH}<3)$ and purified with mixed-mode ion-exchange. An Oasis MCX $\mu$ Elution Plate (Waters, Milford, MA) was preconditioned with $800 \mu \mathrm{L}$ of methanol and equilibrated with $3 \times 800 \mu \mathrm{L}$ of $0.1 \%$ ( $\mathrm{vol} / \mathrm{vol}$ ) TFA in water before peptide samples were loaded on the plate, fol- 
lowed by a washing step with $2 \times 800 \mu \mathrm{L}$ of $0.1 \%$ TFA in water and $2 \times 80 \%(\mathrm{vol} / \mathrm{vol}) \mathrm{ACN} / 0.1 \%(\mathrm{vol} / \mathrm{vol})$ TFA in water. Peptides were eluted with $2 \times 800 \mu \mathrm{L}$ of $10 \%$ (vol $/ \mathrm{vol}$ ) $\mathrm{NH}_{4} \mathrm{OH} / 90 \%$ (vol/vol) methanol. The eluate was evaporated to dryness in a speed vacuum centrifuge and stored at $-80^{\circ} \mathrm{C}$.

\section{SRM Assays}

The SRM method we used was previously developed in our laboratory with the aim to quantify candidate markers for host response directly from crude tissue and body fluid samples, as described in detail by Bislev et al. (2012). A panel of 13 host response proteins was selected: 5 acute phase proteins [including lactoferrin $(\mathbf{L F}), \alpha-2$ macroglobulin (A2M), $\alpha-1$ antitrypsin (A1AT), haptoglobin (HP), and serum amyloid A3 (SAA3)] and 8 proteins previously associated with the onset of bovine host response to mastitis [including cluster of differentiation 14 (CD14), calgranulin B (CALGB, S100-A9), calgranulin C (CALGC, S100-A12), cathepsin C (CATC), vanin-1 (VAN1), galectin-1 (LGALS1), galectin-3 (LGALS3), and IL8]. In the current study, we measured 2 proteotypic tryptic peptides from each protein. Detailed criteria for selecting the target peptides are described in Bislev et al. (2012). We used isotope-labeled reference peptides generated by chemical synthesis; these peptides have the same physiochemical properties as the reference peptides generated by the QconCAT approach used in Bislev et al. (2012), and the origin of reference peptides does not affect the quantification method.

\section{Isotope-Labeled Heavy Standard Peptides}

Isotope-labeled heavy standard peptides corresponding to the 26 targeted proteotypic peptides were purchased as Heavy Peptides AQUA QuantPro incorporating stable isotope-labeled $\mathrm{AA}$, either $\left[{ }^{13} \mathrm{C} 6 /{ }^{15} \mathrm{~N} 2\right]$ Lys or $\left[{ }^{13} \mathrm{C} 6 /{ }^{15} \mathrm{~N} 4\right] \operatorname{Arg}$ (Thermo Scientific, Waltham, MA), with a concentration of $5 \mathrm{pmol} / \mu \mathrm{L}$ in $5 \%$ ( $\mathrm{vol} / \mathrm{vol}$ ) ACN/water. Peptides were pooled to prepare an internal standard solution of $125 \mathrm{fmol} / \mu \mathrm{L}$ of each peptide.

\section{Liquid Chromatography and SRM Analysis of Milk Samples}

The digested and dried protein extracts were reconstituted in $2 \%$ (vol/vol) ACN, $0.1 \%$ (vol/vol) formic acid to $2 \mu \mathrm{g} / \mu \mathrm{L}$ and mixed with the heavy labeled internal standard solution in a 1:1 ratio. For each LC-SRM analysis, $2 \mu \mathrm{L}$ of sample were injected, corresponding to $125 \mathrm{fmol}$ of each standard peptide and representing the peptide equivalents of $2 \mu \mathrm{g}$ of milk protein. Samples were analyzed with a 5500 QTRAP LC-MS system equipped with a NanoSpray Source III and an Eksigent Tempo nano MDLC system (Sciex). Peptides were loaded on a peptide captrap column (Microm Bioresources Inc., Auburn, CA) in 0.1\% (vol/vol) formic acid in water for $5 \mathrm{~min}$ at a flow rate of $5 \mu \mathrm{L} /$ min and separated by a 70-min linear gradient from 2 to $25 \%$ (vol/vol) ACN, $0.1 \%$ (vol/vol) formic acid in water at a flow rate of $300 \mathrm{~nL} / \mathrm{min}$ with an Acclaim PepMap 100 C18 analytical column $(0.75 \times 150 \mathrm{~mm}$, $3 \mu \mathrm{m}$ particles, Dionex, Sunnyvale, CA). Peptides were analyzed in scheduled SRM mode with Q1 and Q3 set to unit resolution, a 2-s cycle time, a 360-s retention time window, a declustering potential of 70 , and an interface heater temperature of $150^{\circ} \mathrm{C}$. As described in Bislev et al. (2012), each peptide sequence was targeted by 10 transitions: 5 transitions for the endogenous light peptide and 5 transitions for the heavy labeled standard. All 36 milk samples were measured in triplicate (technical replicates) for 108 LC-SRM analyses total.

\section{SRM Data Analysis}

The SRM data were processed using Skyline (ver. 2.5; https://skyline.gs.washington.edu, MacLean et al., 2010). Data were manually inspected to ensure correct peak detection and accurate integration. The SRM data and transitions used to measure these proteins were deposited in the PASSEL data repository (http:// www.peptideatlas.org/PASS/PASS01014). Individual protein concentrations were calculated as the mean of the 3 signal intensities from the 2 peptides from each protein (6 intensities per protein).

\section{Statistical Analysis}

All results are presented as least squares means \pm standard error of the mean. Statistical analyses were performed using SAS software (version 9.4, SAS Institute Inc., Cary, NC). The MIXED procedure was used to evaluate changes during the experimental period and differences between the experimental groups. The final model included treatment (LPS vs. PGN), experimental period $(0,4,8,12,24$, and $54 \mathrm{~h})$ and the interaction between both as dependent variables and cow as repeated subject. The concentration of each of the 13 targeted proteins $(\mu \mathrm{g} / \mathrm{mL}$ or $\mathrm{mg} / \mathrm{mL})$ in the original milk samples was calculated from the relative signal intensities (light/heavy), given by spiking 125 fmol of each AQUA standard peptide (Thermo Fisher Scientific) into each of the 36 prepared milk samples. Finally, a Tukey-Kramer test was used to evaluate differences between groups. Values were considered significant when $P<0.05$. 


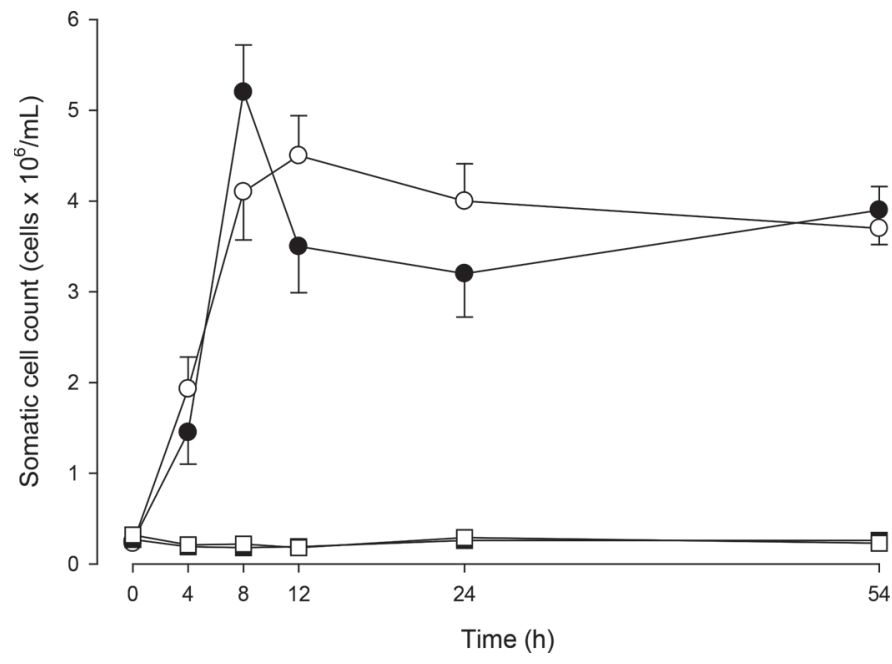

Figure 1. Somatic cell count (LSM \pm SEM) of quarters treated with either LPS $(\mathrm{n}=3 ; \boldsymbol{\bullet})$ or peptidoglycan from Staphylococcus aureus ( $\mathrm{PGN} ; \mathrm{n}=3 ; \mathrm{O})$, as well as the control-LPS $(\mathrm{n}=3$; $)$ and control-PGN $(\mathrm{n}=3 ; \square)$ quarters during the experimental period.

\section{RESULTS}

\section{SCC Increase in Quarters Challenged with LPS and PGN}

Somatic cell counts were measured to monitor extent and timing of host response to LPS and PGN challenge. Figure 1 shows the rise of SCC in quarters challenged with LPS or PGN and also clearly demonstrates that the respective control quarters remain healthy. Milk SCC was significantly increased at $4 \mathrm{~h}(P<0.05)$ in all quarters challenged with either LPS or PGN, and showed the highest SCC at $8 \mathrm{~h}$ for LPS $(P<0.05)$ and at $12 \mathrm{~h}$ for PGN $(P<0.05)$. During the entire experimental period, control quarters remained unchanged $(P$ $>0.05)$.

\section{SRM Analysis of Milk Samples}

All 26 isotope-labeled standard peptides (2 peptides per protein) were readily detected in milk and, therefore, support quantification of the 13 targeted host response proteins. Ten of these 13 proteins were robustly quantified in all 36 milk samples by the detection of the 2 selected proteotypic peptides, whereas 3 proteins, namely CALGC, A2M, and LGALS1, could only be quantified by 1 peptide sequence due to the very low endogenous signal intensity of the second targeted peptide from each of these 3 proteins. The 13 targeted proteins are listed in Table 1 together with their corresponding peptides and measured peptide ions. Supplemental Table S1 and Figure S1 (https:// doi.org/10.3168/jds.2017-14312) provide the concentra- tion and graphical representation, respectively, of the 13 host response proteins measured in milk that has been collected at $0,4,8,12,24$, and 54 h postchallenge.

\section{Acute Phase Proteins Measured in Milk}

Figure 2 shows concentration changes of the acute phase proteins LF (Figure 2A), A2M (Figure 2B), A1AT (Figure 2C), HP (Figure 2D), and SAA3 (Figure 2E) after LPS and PGN challenge over the 54-h period. The concentration of these 5 acute phase proteins increased in milk in the LPS and PGN group $(P<0.05)$ with the exception of A2M, which remained unchanged over time in the PGN group $(P>0.05)$. In the LPS group, A2M, A1AT, HP, and SAA3 increased at both 4 (A2M and A1AT) and $24 \mathrm{~h}$ (HP and SAA3) compared with the PGN group $(P<0.05)$. Lactoferrin shows a remarkable increase over time, but a significant difference between LPS and PGN challenge could not be correlated with the LF levels in milk throughout the entire experimental period $(P>0.05)$.

\section{Cellular Host Response Proteins Measured in Milk}

Figure 3 and 4 show concentration changes of CD14 (Figure 3A), CALGB (Figure 3B), CALGC (Figure 3C), CATC (Figure 3D), VAN1 (Figure 4A), LGALS1 (Figure 4B), LGALS3 (Figure 4C), and IL-8 (Figure $4 \mathrm{D})$ in quarters infused either with LPS or PGN. Overall, the concentration of these 8 proteins significantly increased in both groups $(P<0.05)$, LPS and PGN, with the exception of CD14 and IL-8, which remained unchanged in the PGN group during the entire experimental period $(P>0.05)$. Notably, the majority of the studied proteins increased significantly in greater extent in the LPS group at 4 (VAN1 and IL-8), 8 (IL-8), 12 (CD14, CALGB, and IL-8), and $24 \mathrm{~h}$ (CD14, CATC, LGALS1, LGALS3, and IL-8) compared with the PGN group $(P<0.05)$. For VAN1, a relatively low concentration change over the experiment in the PGN group was observed, although VAN1 significantly increased at $4 \mathrm{~h}$ in this group. For CALGC, no differences in concentration was observed between the 2 groups over the experiment $(P>0.05)$.

\section{DISCUSSION}

The activation of bovine host response to mastitis is tailored to fight the different invading mammary pathogenic bacteria (Wellnitz et al., 2013). Whereas LPS has been widely used to simulate $E$. coli-mediated mastitis by both in vivo and in vitro experiments, (Wellnitz et al., 2011; Wall et al., 2016a,b), PGN has so far only 
been reported for in vitro simulation of mastitis caused by Staph. aureus (Mount et al., 2009; Im et al., 2014; Sulabh et al., 2016). Based on the increased SCC in both of our experimental groups, we concluded that PGN is suitable for experimental simulation of mastitis caused by Staph. aureus. Thus, we present for the first time a parallel study to compare the bovine host response to E. coli- and Staph. aureus-mediated challenge, measured by the timed regulation of 13 host response proteins in milk samples collected after intramammary LPS and PGN challenges.

\section{General Observations}

Generally, all 13 targeted proteins increased their concentration in milk after challenge, and cows challenged with LPS showed a larger increase of these proteins in milk compared with those challenged with PGN. These observations are in agreement with previous transcriptome studies that compared E. coli and Staph. aureus mastitis in cows (Lee et al., 2006; Mount et al., 2009). Likewise, ELISA-based studies (Riollet et al., 2000; Bannerman et al., 2004; Pyörälä et al., 2011) have reported that gram-negative bacteria unleash a more acute and severe host response than gram-positive bacteria. In the present study, 6 host response proteins, namely CALGC, CATC, VAN1, LGALS1, and
LGALS3, were measured in milk after in vivo challenge with either LPS or PGN.

\section{Biomarker Candidates for Mastitis Detection and Diagnosis}

Our present study clearly demonstrates that the acute phase proteins A2M and A1AT show very early an increased concentration in cows challenged with LPS compared with those challenged with PGN. Therefore, both proteins are good candidates for early detection of mastitis caused by gram-negative bacteria. Both A2M and $\mathrm{A} 1 \mathrm{AT}$ are protease inhibitors synthesized mainly in the liver in response to inflammation, and both are important regulators of the bulk of proteases that are released upon injury (Murata et al., 2004). Both A2M and A1AT are found in milk due to the increased permeability of the blood-milk barrier during inflammation. Our results are in agreement with previous studies that reported higher A1AT concentrations in bovine milk sampled from coliform mastitis compared with staphylococcal mastitis (Pyörälä and Syväjärvi, 1987). Similar observations about A2M are not available in the literature; thus, our study also present a first time observation on A2M response in challenged cows.

The acute phase proteins SAA3 and HP, which are known to be expressed locally by mammary gland cells

Table 1. Target proteins, their corresponding 2 proteotypic peptides, and transitions used in the selected reaction monitoring analysis

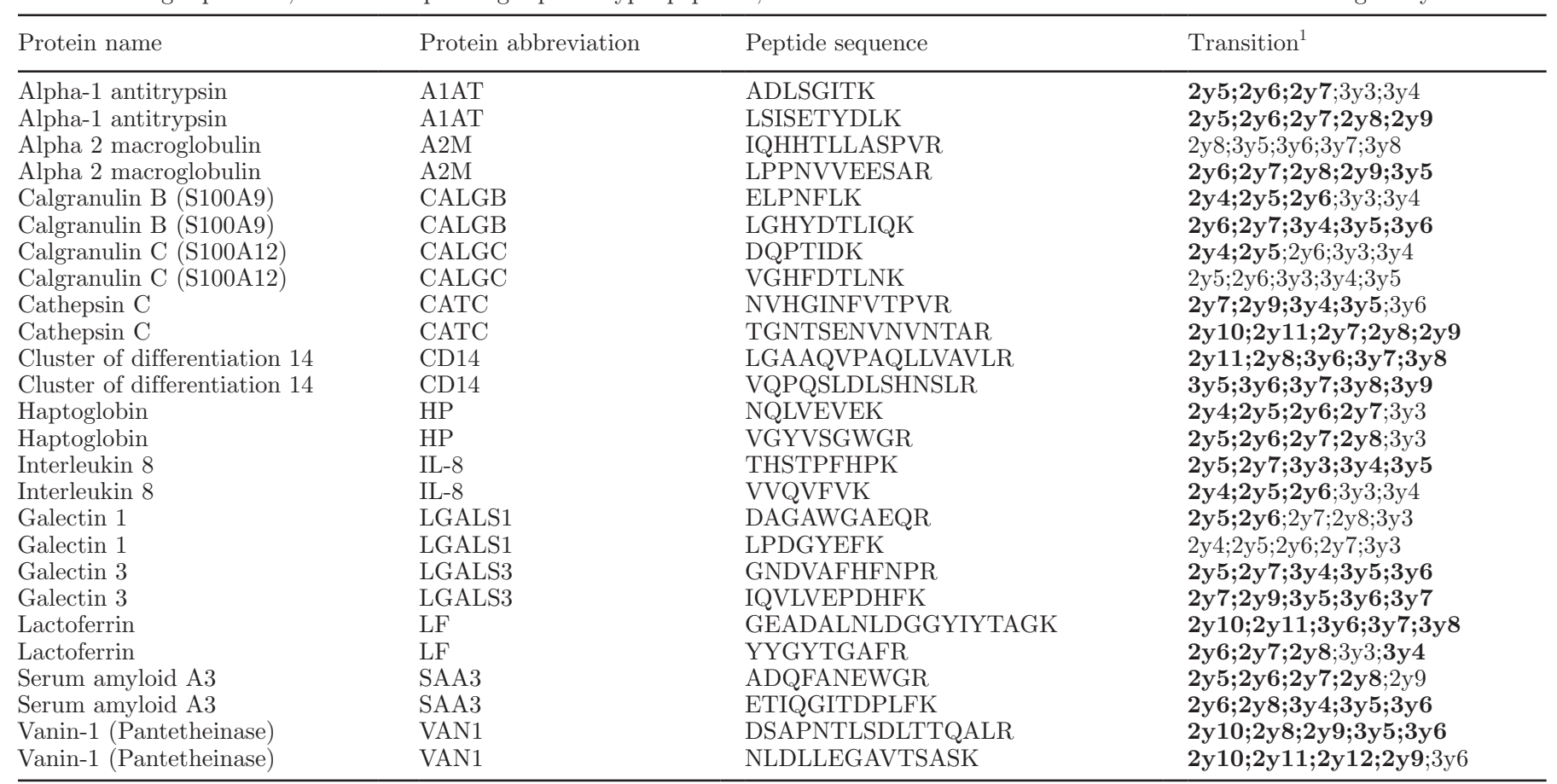

${ }^{1}$ Q3 ions that passed the manual verification step and were used in this study for quantification are highlighted in bold. Q3 ions are named according to the precursor charge state and fragment ion position in the y ion series; hence, $2 \mathrm{y} 6$ refers to a y6 fragment ion derived from the doubly charged precursor ion. 
A

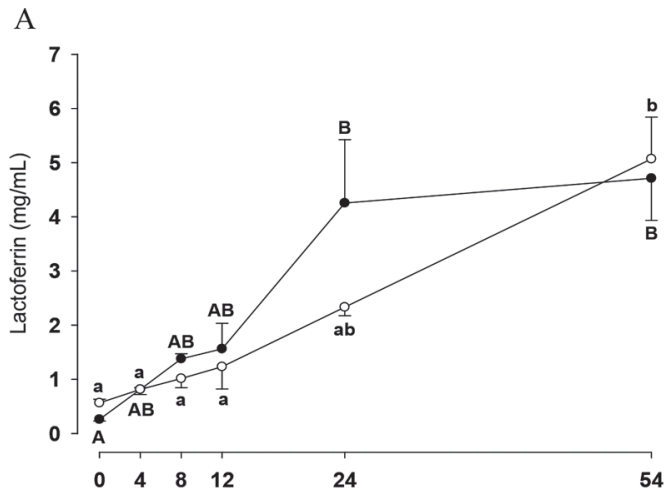

C

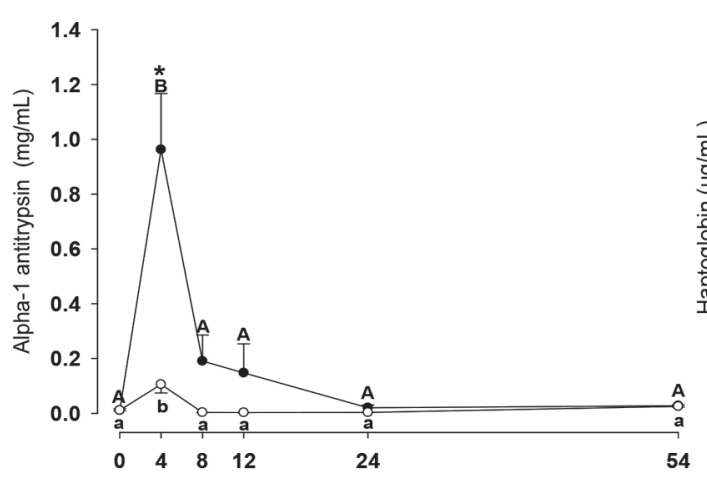

E

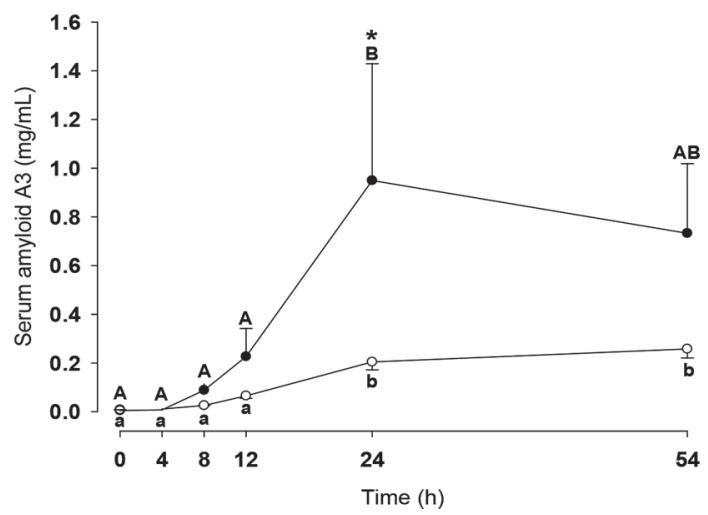

B

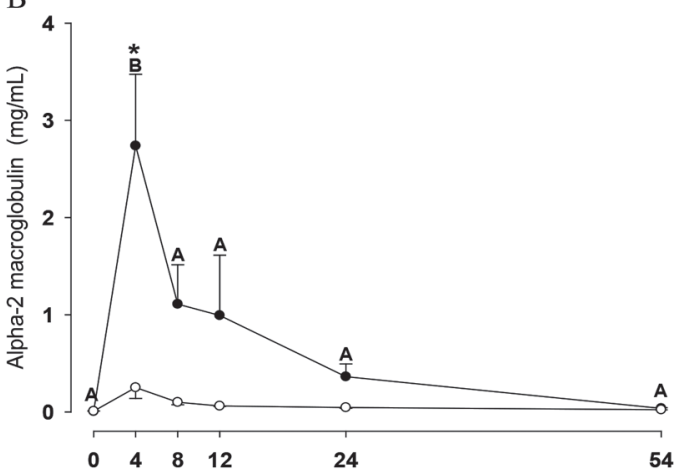

D

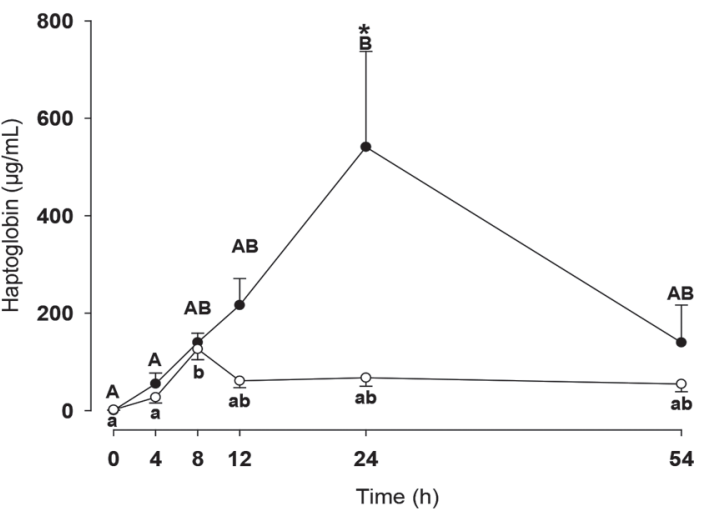


A

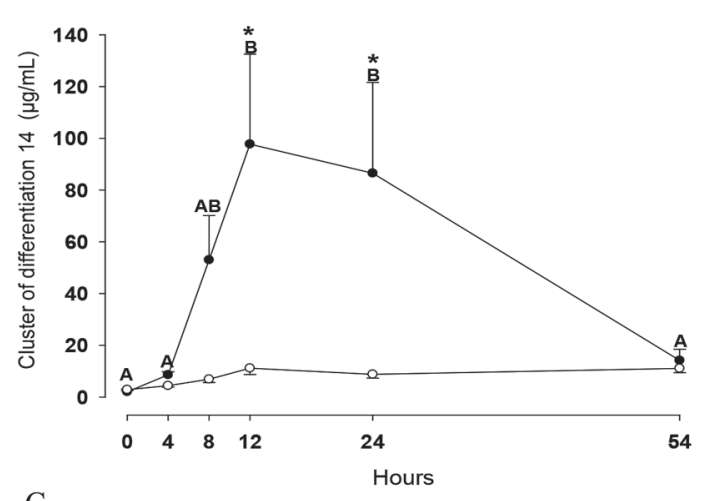

C

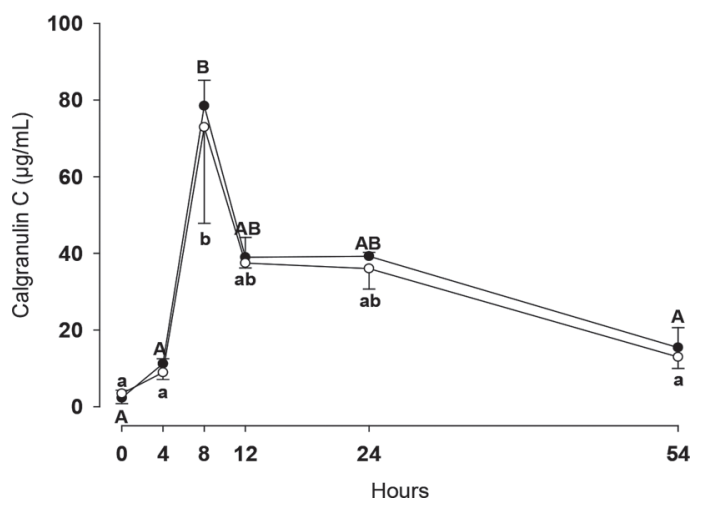

B

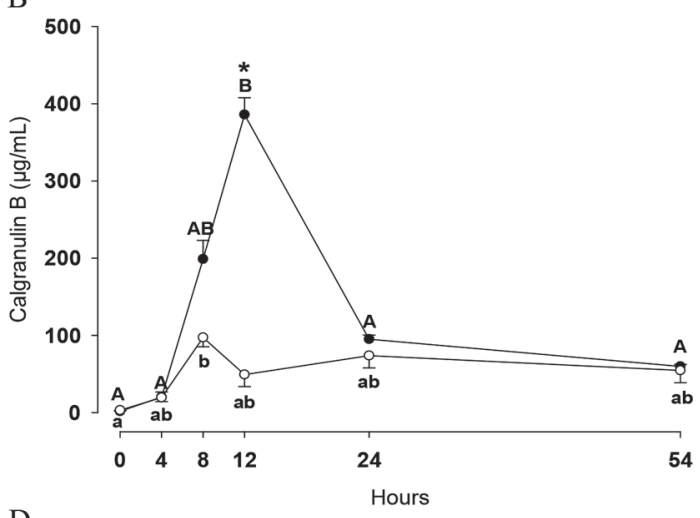

D

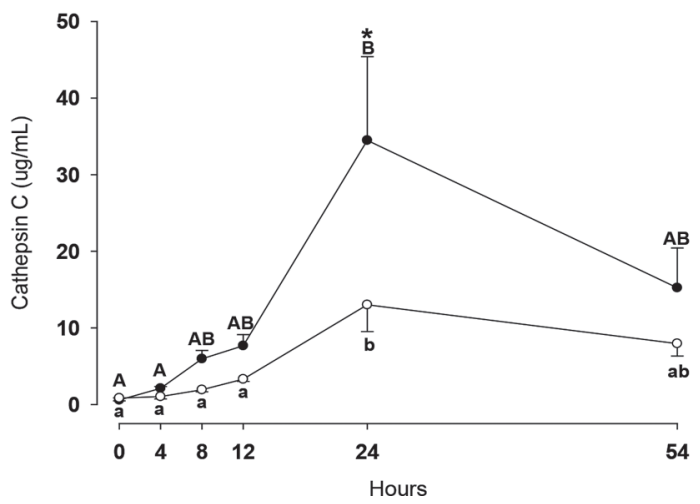

Figure 3. Cluster of differentiation 14 (A), calgranulin B (B), calgranulin C (C), and cathepsin C (D) concentrations (LSM \pm SEM) in quarters treated with either LPS $(\mathrm{n}=3 ; \bullet)$ or peptidoglycan from Staphylococcus aureus (PGN; $\mathrm{n}=3$; O) during the experimental period. Different uppercase letters (A,B) indicate significant differences between time points within LPS group $(P<0.05)$. Different lowercase letters $(\mathrm{a}, \mathrm{b})$ indicate significant differences between time points within PGN group $(P<0.05)$. Consecutive time points labeled with the same letters (e.g., A-A and a-a) denote that protein changes were not significantly different $(P>0.05)$ between these 2 time points. *Significant differences between LPS and PGN groups at the marked time point $(P<0.05)$.

(2011) showed low concentrations for HP $(33 \mathrm{mg} / \mathrm{L})$ and SAA3 $(16.4 \mathrm{mg} / \mathrm{L})$ in cows infected with Staph. aureus (our concentrations for HP and SAA3 in cows $12 \mathrm{~h}$ postchallenge with PGN were $54.36 \pm 11.04$ and 65.12 $\pm 1.54 \mu \mathrm{g} / \mathrm{mL}$, respectively). Therefore, our observations are in agreement with the results from Pyörälä et al. (2011), who also suggested that HP and SAA3 can reflect the severity of clinical mastitis.

Although LF has been considered as a suitable marker for mastitis, its concentration increased but did not differ between the LPS and the PGN group. Some controversy exists about the specific LF concentration during mastitis, as several authors have reported similarly increased LF concentrations during mastitis caused either by E. coli or Staph. aureus (Kawai et al., 1999; Griesbeck-Zilch et al., 2008).

In addition to acute phase proteins, several immune cells (and their secreted substances) are involved in the host response during mastitis. It is well known that bacteria invading the mammary gland can cause patho- gen-specific differential permeability of the blood-milk barrier (Wellnitz et al., 2016), which affect the transfer of blood components into the milk (Wellnitz et al., 2011). Pathogens such as E. coli have a greater effect on the blood-milk barrier and, consequently, a larger transfer of blood proteins to milk occurs in comparison to mastitis caused by Staph. aureus (Bannerman et al., 2004). Therefore, proteins secreted by immune cells during the host response to mastitis causing pathogens could be considered as useful biomarkers, which additionally can provide information about the severity and stage of mastitis infections (Bannerman et al., 2004). In our study, diverse proteins related to the immune response such as CD14, CALGB, CATC, LGALS1, LGALS3, and IL-8 were increased in cows challenged with LPS compared with those challenged with PGN. These observations support previous ELISA-based studies by Persson Waller et al. (2003) and Bannerman et al. (2004), who reported different increase patterns of CD14 and IL-8 in milk from cows with mastitis caused 


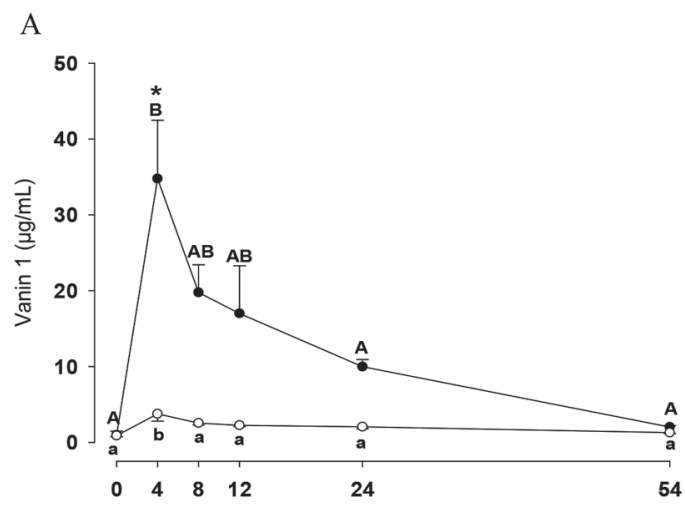

B
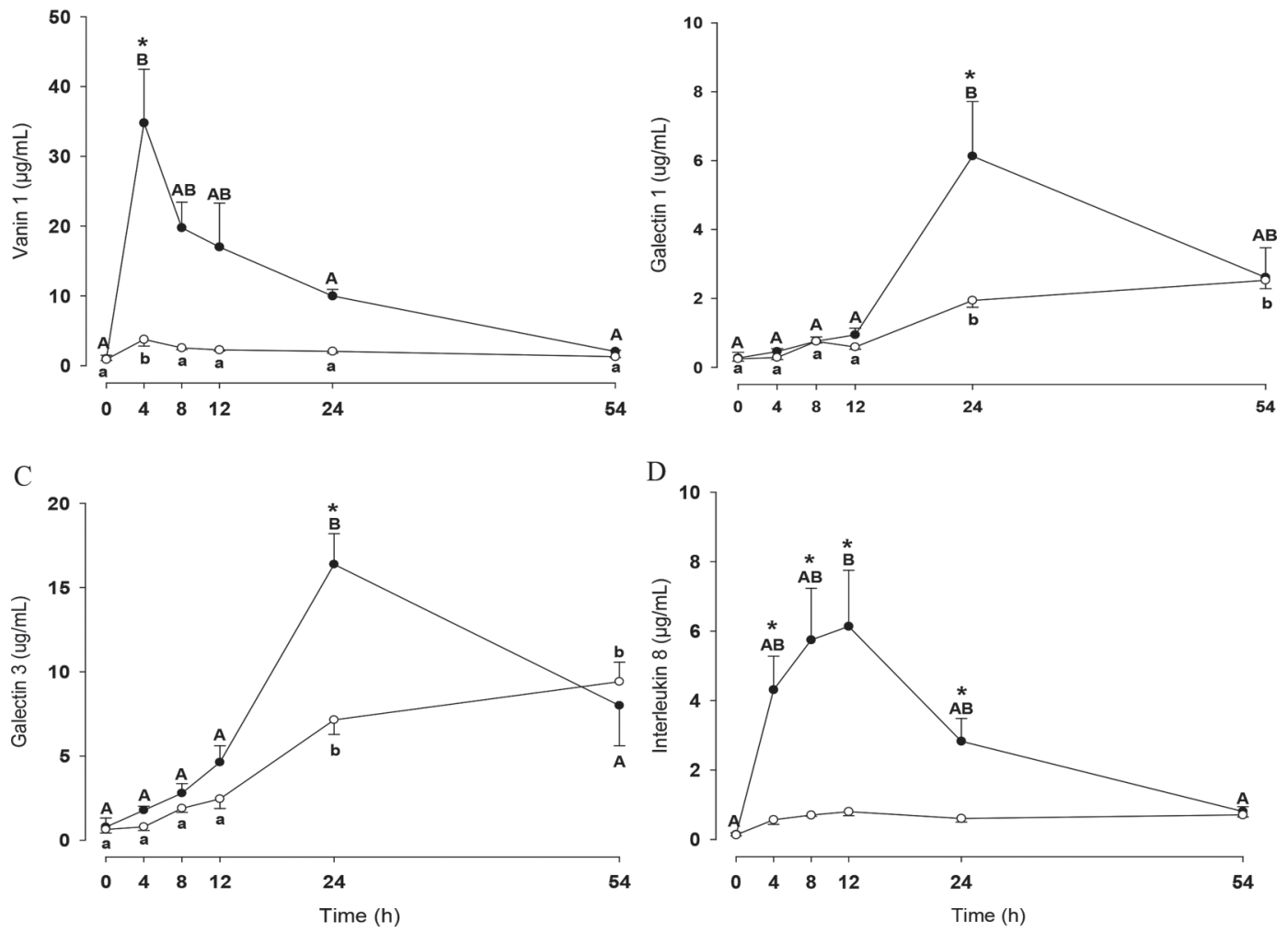

Figure 4. Vanin 1 (A), galectin 1 (B), galectin 3 (C), and IL-8 (D) concentrations (LSM \pm SEM) in quarters treated with either LPS (n $=$ 3; -) or peptidoglycan from Staphylococcus aureus (PGN; $\mathrm{n}=3$; $\mathrm{O}$ ) during the experimental period. Different uppercase letters (A,B) indicate significant differences between time points within LPS group $(P<0.05)$. Different lowercase letters $(\mathrm{a}, \mathrm{b})$ indicate significant differences between time points within PGN group $(P<0.05)$. Consecutive time points labeled with the same letters (e.g., A-A and a-a) denote that protein changes were not significantly different $(P>0.05)$ between these 2 time points. *Significant differences between LPS and PGN groups at the marked time point $(P<0.05)$.

by either E. coli or Staph. aureus. Additionally, Bislev et al. (2012) showed increased concentrations of CD14, CALGB, CATC, LGALS1, LGALS3, and IL-8 in mammary gland tissue as a consequence of the IMI with Streptococcus uberis; however, the present study shows for the first time that these proteins can be directly measured in milk. Consequently, we suggest that also the 7 immune related proteins we report here (CD14, CALGB, CALGC, CATC, LGALS1, LGALS3, and IL-8), are interesting candidates for their use as clinical markers for mastitis detection. Thus, these protein patterns may be used for the identification of the type of bacteria causing mastitis (gram-negative vs. grampositive). For example, we observed that CALGC is increased in mastitis caused by either gram-negative or gram-positive bacteria, whereas CD14 is only increased in mastitis caused by gram-negative bacteria. The fact that we can detect and quantify IL-8 and CD14 and other immune-related proteins, such as CALGB, CALBC, CATC, LGALS1, and LGALS3, by targeted proteomics reflects the strength and potential of the SRM method for further validation and research in large-scale animal experiments. Additionally, VAN1 showed a pathogendependent response during the mastitis challenge in our study. Despite its relatively low concentration in milk, we robustly quantified concentration changes of this protein in all 36 milk samples, having a remarkable response $4 \mathrm{~h}$ after LPS challenge. Vanin-1 is a GPIanchored cell-specific surface pantetheinase, which, upon pantetheine (CoA precursor) hydrolysis, provides cysteamine to tissues. This protein has been described to have a role in inflammation, oxidative stress, and cell migration (Kaskow et al., 2012). In addition, a previous study in human gut demonstrated a proinflammatory role of VAN1 in relation to colitis (Berruyer et al., 2006). In a previous publication from our group, we showed increased VAN1 concentrations in bovine mammary gland tissue infected with Streptococcus uberis (Bislev et al., 2012). The present study shows for the first time the quantification of VAN1 in milk. 


\section{Relevance of Biomarkers in the Dairy Industry}

From the 13 proteins we presented in this study, 11 proteins showed increased concentrations upon challenge, and 7, namely A2M, CALGB, CALBC, CATC, LGALS1, LGALS3, and VAN1, are described for the first time in either LPS- or PGN-challenged cows. We suggest that A2M, A1AT, VAN1, and IL-8 are the most pertinent candidates for future investigations regarding their relevance in mastitis detection and diagnosis. Our considerations are based on their early (A2M, A1AT, and VAN1) or long-term (IL-8) increased concentration after LPS challenge compared with PGN challenge. However, monitoring fluctuations of all 11 potential biomarkers may become valuable as early indicators of mastitis caused by gram-negative bacteria, particularly if fast and accurate assays can be implemented in routine on-line detection during milking in automatic milking robots. It should be noted that all biomarker candidates described here must be further validated in a large-scale animal experiment to fully evaluate their potential as biomarkers for mastitis detection and diagnosis. Based on our results and due to the high throughput and low cost, our SRM approach can provide the means to measure large sets of milk samples, including both biological replicates and frequent sampling times to further investigate the potentials and general value of these markers.

\section{CONCLUSIONS}

We clearly demonstrated an increase in the concentration of 11 host response proteins in cows challenged by LPS, reflecting a more acute inflammatory response in mastitis caused by E. coli compared with PGN challenge. Likewise, our observations of an impaired inflammatory response to PGN may contribute to the well-known ability of Staph. aureus to establish chronic IMI. Potential biomarker candidates for distinguishing gram-negative mastitis from gram-positive mastitis include A2M, A1AT, HP, SAA3, CD14, CALGB, CATC, VAN1, LGALS1, LGALS3, and IL-8. The targeted quantitative SRM mass spectrometry approach described here can be used as a validation method of these noninvasive biomarkers in large-scale experiments.

\section{ACKNOWLEDGMENTS}

This work was carried out in a BIOSENS Consortium project and was financed by the Danish Ministry of Food Agriculture and Fisheries, Lattec I/S (Copenhagen, Denmark), The Milk Levy Fund (Copenhagen, Denmark), the Faculty of Agriculture Sciences and the Graduate School of Agriculture, Food and Environment at Aarhus University (Aarhus, Denmark). Ulrike Kusebauch was supported by a fellowship of the German Academic Exchange Service (Bonn, Germany), National Institutes of Health, National Institute for General Medical Sciences (grant R01 GM087221) and Center for Systems Biology (grant 2P50 GM076547; Washington, DC), the National Human Genome Research Institute and the American Recovery and Reinvestment Act (ARRA; grant RC2 HG005805; Washington, DC), and the National Science Foundation MRI (grant 0923536; Alexandria, VA).

\section{REFERENCES}

Aitken, S. L., C. M. Corl, and L. M. Sordillo. 2011. Immunopathology of mastitis: Insights into disease recognition and resolution. J. Mammary Gland Biol. Neoplasia 16:291-304.

Bannerman, D. D. 2009. Pathogen-dependent induction of cytokines and other soluble inflammatory mediators during intramammary infection of dairy cows. J. Anim. Sci. 87:10-25.

Bannerman, D. D., M. J. Paape, J. W. Lee, X. Zhao, J. C. Hope, and P. Rainard. 2004. Escherichia coli and Staphylococcus aureus elicit differential innate immune responses following intramammary infection. Clin. Diagn. Lab. Immunol. 11:463-472.

Berruyer, C., L. Pouyet, V. Millet, F. M. Martin, A. LeGoffic, A. Canonici, S. Garcia, C. Bagnis, P. Naquet, and F. Galland. 2006. Vanin-1 licenses inflammatory mediator production by gut epithelial cells and controls colitis by antagonizing peroxisome proliferatoractivated receptor $\gamma$ activity. J. Exp. Med. 203:2817-2827.

Bislev, S. L., U. Kusebauch, M. C. Codrea, R. J. Beynon, V. M. Harman, C. M. Rontved, R. Aebersold, R. L. Moritz, and E. Bendixen. 2012. Quantotypic properties of QconCAT peptides targeting bovine host response to Streptococcus uberis. J. Proteome Res. 11:1832-1843.

Boehmer, J. L. 2011. Proteomic analyses of host and pathogen responses during bovine mastitis. J. Mammary Gland Biol. Neoplasia 16:323-338.

Burvenich, C., V. r. Van Merris, J. Mehrzad, A. Diez-Fraile, and L. Duchateau. 2003. Severity of E. coli mastitis is mainly determined by cow factors. Vet. Res. 34:521-564.

Danielsen, M., M. C. Codrea, K. L. Ingvartsen, N. C. Friggens, E. Bendixen, and C. M. Rontved. 2010. Quantitative milk proteomicsHost responses to lipopolysaccharide-mediated inflammation of bovine mammary gland. Proteomics 10:2240-2249.

Domon, B., and R. Aebersold. 2010. Options and considerations when selecting a quantitative proteomics strategy. Nat. Biotechnol. $28: 710-721$.

Ebhardt, H. A., A. Root, C. Sander, and R. Aebersold. 2015. Applications of targeted proteomics in systems biology and translational medicine. Proteomics 15:3193-3208.

Eckersall, P. D., F. J. Young, A. M. Nolan, C. H. Knight, C. McComb, M. M. Waterston, C. J. Hogarth, E. M. Scott, and J. L. Fitzpatrick. 2006. Acute phase proteins in bovine milk in an experimental model of Staphylococcus aureus subclinical mastitis. J. Dairy Sci. 89:1488-1501.

Fogsgaard, K. K., C. M. Røntved, P. Sørensen, and M. S. Herskin. 2012. Sickness behavior in dairy cows during Escherichia coli mastitis. J. Dairy Sci. 95:630-638.

Griesbeck-Zilch, B., H. H. Meyer, C. H. Kuhn, M. Schwerin, and O. Wellnitz. 2008. Staphylococcus aureus and Escherichia coli cause deviating expression profiles of cytokines and lactoferrin messenger ribonucleic acid in mammary epithelial cells. J. Dairy Sci. 91:2215-2224.

Hernández-Castellano, L. E., A. M. Almeida, M. Ventosa, A. V. Coelho, N. Castro, and A. Arguello. 2014. The effect of colostrum intake on blood plasma proteome profile in newborn lambs: Low abundance proteins. BMC Vet. Res. 10:85. 
Hernández-Castellano, L. E., A. Arguello, A. M. Almeida, N. Castro, and E. Bendixen. 2015. Colostrum protein uptake in neonatal lambs examined by descriptive and quantitative liquid chromatography-tandem mass spectrometry. J. Dairy Sci. 98:135-147.

Hernández-Castellano, L. E., A. M. Ferreira, P. Nanni, J. Grossmann, A. Arguello, J. Capote, G. Cai, J. Lippolis, N. Castro, and A. M. Almeida. 2016. The goat (Capra hircus) mammary gland secretory tissue proteome as influenced by weight loss: A study using label free proteomics. J. Proteomics 145:60-69.

Hernández-Castellano, L. E., L. L. Hernandez, H. Sauerwein, and R. M. Bruckmaier. 2017b. Endocrine and metabolic changes in transition dairy cows are affected by prepartum infusions of a serotonin precursor. J. Dairy Sci. 100:5050-5057.

Hernández-Castellano, L. E., S. K. Wall, R. Stephan, S. Corti, and R. Bruckmaier. 2017a. Milk somatic cell count, lactate dehydrogenase activity, and immunoglobulin G concentration associated with mastitis caused by different pathogens: A field study. Schweiz. Arch. Tierheilkd. 159:283-290.

Hiss, S., M. Mielenz, R. M. Bruckmaier, and H. Sauerwein. 2004. Haptoglobin concentrations in blood and milk after endotoxin challenge and quantification of mammary $\mathrm{Hp}$ mRNA expression. J. Dairy Sci. 87:3778-3784.

Hogeveen, H., K. Huijps, and T. Lam. 2011. Economic aspects of mastitis: New developments. N. Z. Vet. J. 59:16-23.

Im, J., T. Lee, J. H. Jeon, J. E. Baik, K. W. Kim, S.-S. Kang, C.-H. Yun, H. Kim, and S. H. Han. 2014. Gene expression profiling of bovine mammary gland epithelial cells stimulated with lipoteichoic acid plus peptidoglycan from Staphylococcus aureus. Int. Immunopharmacol. 21:231-240.

Kaskow, B. J., J. Michael Proffit, J. Blangero, E. K. Moses, and L. J. Abraham. 2012. Diverse biological activities of the vascular noninflammatory molecules - The Vanin pantetheinases. Biochem. Biophys. Res. Commun. 417:653-658.

Kawai, K., S. Hagiwara, A. Anri, and H. Nagahata. 1999. Lactoferrin concentration in milk of bovine clinical mastitis. Vet. Res. Commun. 23:391-398.

Kusebauch, U., D. S. Campbell, E. W. Deutsch, C. S. Chu, D. A. Spicer, M. Y. Brusniak, J. Slagel, Z. Sun, J. Stevens, B. Grimes, D. Shteynberg, M. R. Hoopmann, P. Blattmann, A. V. Ratushny, O. Rinner, P. Picotti, C. Carapito, C. Y. Huang, M. Kapousouz, H. Lam, T. Tran, E. Demir, J. D. Aitchison, C. Sander, L. Hood, R. Aebersold, and R. L. Moritz. 2016. Human SRMAtlas: A resource of targeted assays to quantify the complete human proteome. Cell 166:766-778.

Lee, J.-W., D. D. Bannerman, M. J. Paape, M.-K. Huang, and X. Zhao. 2006. Characterization of cytokine expression in milk somatic cells during intramammary infections with Escherichia coli or Staphylococcus aureus by real-time PCR. Vet. Res. 37:219-229.

MacLean, B., D. M. Tomazela, N. Shulman, M. Chambers, G. L. Finney, B. Frewen, R. Kern, D. L. Tabb, D. C. Liebler, and M. J. MacCoss. 2010. Skyline: An open source document editor for creating and analyzing targeted proteomics experiments. Bioinformatics 26:966-968.

Mount, J. A., N. A. Karrow, J. L. Caswell, H. J. Boermans, and K. E. Leslie. 2009. Assessment of bovine mammary chemokine gene expression in response to lipopolysaccharide, lipotechoic acid plus peptidoglycan, and CpG oligodeoxynucleotide 2135. Can. J. Vet. Res. 73:49-57.

Murata, H., N. Shimada, and M. Yoshioka. 2004. Current research on acute phase proteins in veterinary diagnosis: An overview. Vet. J. 168:28-40.

Persson Waller, K., I. G. Colditz, S. Lun, and K. Östensson. 2003. Cytokines in mammary lymph and milk during endotoxin-induced bovine mastitis. Res. Vet. Sci. 74:31-36.
Picotti, P., and R. Aebersold. 2012. Selected reaction monitoringbased proteomics: Workflows, potential, pitfalls and future directions. Nat. Methods 9:555-566.

Pyörälä, S., M. Hovinen, H. Simojoki, J. Fitzpatrick, P. D. Eckersall, and T. Orro. 2011. Acute phase proteins in milk in naturally acquired bovine mastitis caused by different pathogens. Vet. Rec. 168:535.

Pyörälä, S., and J. Syväjärvi. 1987. Bovine acute mastitis part I. Clinical aspects and parameters of inflammation in mastitis caused by different pathogens. Zentralbl. Veterinarmed. B 34:573-584.

Riollet, C., P. Rainard, and B. Poutrel. 2000. Differential induction of complement fragment C5a and inflammatory cytokines during intramammary infections with Escherichia coli and Staphylococcus aureus. Clin. Diagn. Lab. Immunol. 7:161-167.

Schukken, Y. H., J. Günther, J. Fitzpatrick, M. C. Fontaine, L. Goetze, O. Holst, J. Leigh, W. Petzl, H. J. Schuberth, A. Sipka, D. G. E. Smith, R. Quesnell, J. Watts, R. Yancey, H. Zerbe, A. Gurjar, R. N. Zadoks, and H. M. Seyfert. 2011. Host-response patterns of intramammary infections in dairy cows. Vet. Immunol. Immunopathol. 144:270-289.

Sulabh, S., B. Bhushan, M. Panigrahi, A. Verma, N. A. Baba, and P. Kumar. 2016. Differential response of immune-related genes to peptidoglycan and lipoteichoic acid challenge in vitro. Vet. World 9:983-988

Torres, A., L. E. Hernández-Castellano, A. Morales-delaNuez, D. Sánchez-Macías, I. Moreno-Indias, N. Castro, J. Capote, and A. Argüello. 2014. Short-term effects of milking frequency on milk yield, milk composition, somatic cell count and milk protein profile in dairy goats. J. Dairy Res. 81:275-279.

Vels, L., C. M. Røntved, M. Bjerring, and K. L. Ingvartsen. 2009. Cytokine and acute phase protein gene expression in repeated liver biopsies of dairy cows with a lipopolysaccharide-induced mastitis. J. Dairy Sci. 92:922-934.

Wall, S. K., L. E. Hernandez-Castellano, A. Ahmadpour, R. M. Bruckmaier, and O. Wellnitz. 2016a. Differential glucocorticoid-induced closure of the blood-milk barrier during lipopolysaccharide- and lipoteichoic acid-induced mastitis in dairy cows. J. Dairy Sci. 99:7544-7553.

Wall, S. K., O. Wellnitz, L. E. Hernandez-Castellano, A. Ahmadpour, and R. M. Bruckmaier. 2016b. Supraphysiological oxytocin increases the transfer of immunoglobulins and other blood components to milk during lipopolysaccharide- and lipoteichoic acidinduced mastitis in dairy cows. J. Dairy Sci. 99:9165-9173.

Wellnitz, O., E. T. Arnold, and R. M. Bruckmaier. 2011. Lipopolysaccharide and lipoteichoic acid induce different immune responses in the bovine mammary gland. J. Dairy Sci. 94:5405-5412.

Wellnitz, O., E. T. Arnold, M. Lehmann, and R. M. Bruckmaier. 2013. Short communication: Differential immunoglobulin transfer during mastitis challenge by pathogen-specific components. J. Dairy Sci. 96:1681-1684.

Wellnitz, O., C. Zbinden, X. Huang, and R. M. Bruckmaier. 2016. Short communication: Differential loss of bovine mammary epithelial barrier integrity in response to lipopolysaccharide and lipoteichoic acid. J. Dairy Sci. 99:4851-4856.

Yang, W., H. Zerbe, W. Petzl, R. M. Brunner, J. Günther, C. Draing, S. von Aulock, H.-J. Schuberth, and H.-M. Seyfert. 2008. Bovine TLR2 and TLR4 properly transduce signals from Staphylococcus aureus and $E$. coli, but $S$. aureus fails to both activate NF- $\kappa \mathrm{B}$ in mammary epithelial cells and to quickly induce $\mathrm{TNF} \alpha$ and interleukin-8 (CXCL8) expression in the udder. Mol. Immunol. 45:1385-1397. 